\title{
Emotional intelligence and learning outcomes: Study in physical education
}

\author{
Albertus Fenanlampir ${ }^{1 \mathrm{abcde}, *(\mathbb{D}, \text { Toho Cholik Mutohir }}{ }^{2 \mathrm{abcde}}$ \\ Universitas Pattimura, Indonesia ${ }^{1}$ \\ Universitas Negeri Surabaya, Indonesia ${ }^{2}$
}

Received: 04 May 2021; Accepted 04 August 2021; Published 28 August 2021

Ed 2021; 6(3): 304-314

\begin{abstract}
The correlation between emotional intelligence and learning outcomes of elementary school students in physical education is still minimal. Therefore, a deeper exploration in this study is carried out to reveal it. This study aims to analyze the correlation between emotional intelligence and students' physical education learning outcomes in elementary schools. This correlational study aims to analyze the relationship between emotional intelligence and elementary school students' learning outcomes in physical education. The ANOVA correlation between emotional intelligence and physical education learning outcomes shows a significance value of 0.224 , greater than alpha 0.05 . It means that there is no correlation between emotional intelligence and students' cognitive learning outcomes in physical education subjects. Factors that contribute to the absence of a relationship between emotional intelligence and learning outcomes include implementing online learning that is less than optimal because it is not supported by adequate facilities and learning participation by all students. The other factors are reduced or limited interaction between students and the learning environment, the economic burden that causes parents' emotional problem that impacts children's emotions. The contribution of emotional intelligence to the achievement of learning outcomes, especially in physical education subjects, is as much as $2 \%$, and other factors contribute as much as $98 \%$.
\end{abstract}

Keywords: Emotional intelligence; learning outcomes; physical education

https://doi.org/10.25299/sportarea.2021.vol6(3).6836

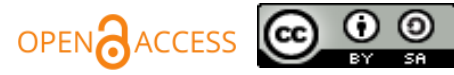

Copyright @ 2021 Albertus Fenanlampir, Toho Cholik Mutohir

Corresponding Author: Albertus Fenanlampir, Department of Physical Education Health and Recreation, Faculty of Teacher Training and Education, Universitas Pattimura, Ambon, Maluku, Indonesia

Email: fenanlampir29@gmail.com

How to Cite: Fenanlampir, A., \& Mutohir, T. C. (2021). Emotional intelligence and learning outcomes: Study in physical education. Journal Sport Area, 6(3), 304-3014. https://doi.org/10.25299/sportarea.2021.vol6(3).6836

Authors' Contribution: a - Study Design; b - Data Collection; c - Statistical Analysis; d - Manuscript Preparation; e - Funds Collection

\section{INTRODUCTION}

In the previous few centuries, there has been a belief in sports that physical activity is closely related to intellectual ability (Zeng et al., 2017). However, to date, the relationship between physical activity and mental function has not been systematically evaluated and even published. Other information conveys that research on the psychology of physical activity has been carried out in the 1950s to 1980s (Janssen \& Leblanc, 2015). This can be seen that the shift in research activities is more directed at physical and mental exercises related to emotional intelligence and self-regulation (Tomporowski et al., 2008). Children's participation in games and activities is considered very important in learning because students are more likely to play while learning (de Souza et al., 2020). This is because students are still in their growth and 
development. Therefore, it needs assistance from teachers in training skills and knowledge for students. The sport requires physical activity, both indoors and outdoors, with the aim of training children's mental and emotional development (Liu et al., 2017). The results of a study in Russia for elementary school students show that emotional intelligence can increase student learning outcomes and lead to students' emotional development in a positive direction (Yan et al., 2011).

Learning activities are highly dependent on a person's emotional state (Chen \& Guo, 2020). Suppose students have too much anxiety and tension or too much emotion. In that case, they tend to interfere with the early stages of learning, especially in motion material (Sukys et al., 2019). Students who are just starting to learn to move find it difficult to practice it well. This can be found in the stage of learning the basics of the game, such as in football, or the mandatory elements in parallel bar numbers, and so on (Chan \& Mallett, 2011). Thus, in general, learning requires supportive emotional intelligence, including physical education in schools (Lee et al., 2020). Emotional intelligence can help the mind understand emotions and emotional information to improve emotional and intellectual development and understand and regulate emotions reflectively (Leasa et al., 2017). Emotional intelligence is the ability to manage emotions and moods, both in oneself and others (Jan \& Anwar, 2019). Emotionally intelligent people can be more openly positive and understand their internal experiences to classify things and communicate with others appropriately (Ingram et al., 2019). Good emotional intelligence can help achieve maximum learning outcomes (Longobardi et al., 2020).

Learning outcomes, in general, have a focus on cognitive representations that guide one's behavior towards the ultimate goal related to competence (Koh et al., 2014). This is referred to as the internal goal or effort that a person has for a particular situation. Individuals to achieve mastery tackle tasks with learning objectives for their own sake (Omer, 2018). Individuals who have reasonable performance goals always strive to get favorable ratings, perform better than others, or avoid negative judgments from others (Berkovits, 2014). There has not been much information that reveals the relationship between learning outcomes and emotional intelligence simultaneously in physical education in Indonesia. This is proven by several previous studies which explain that emotional intelligence can improve one's sports achievement (Galarraga et al., 2020). Another research conducted by Arikan (2020) explains that virtual learning can improve students' emotional intelligence. This can be seen from the development of education that encourages emotional intelligence such as Singapore and Tasmania are developed countries in the world and in their curriculum have developed a physical education syllabus so that students must acquire the right knowledge, skills, attitudes, social emotional, and values for life (Ang \& Penney, 2013). Physical education is one of the most important learning content in developing learning outcomes, including aspects of students' emotional intelligence (Vaughan et al., 2019).

Teachers can apply various approaches in learning activities according to class conditions, the material being taught, and the level of the education unit (Darling-hammond et al., 2019). The various approaches used each have their advantages and limitations. Teachers must be proficient and master the teaching materials well and the models and learning methods used (Batlolona \& Souisa, 2020). In general, the approach often used by teachers is teacher-centered learning and student-centered learning, regardless of what strategies, methods, and learning techniques will be used by the teacher (Goodyear \& Dudley, 2015). To support mastery of the material and student learning outcomes during learning at school, especially those use cooperative learning models, the division of groups students need to pay attention to the level of students' intelligence (academic abilities, high, medium, and low) so that the learning process can run well to ensure the group can achieve good learning outcomes (Leasa et al., 2021).

The treatment of students who have the low academic ability and are not competent or slow in the learning process should be appropriate (Leasa et al., 2016). There is a kind of time discrimination and coercion in capturing teaching materials and completing their work because learning outcomes are always individual even though the learning process is carried out in groups or together (Batlolona et al., 2020). Learning in groups means that the teacher has ignored individual differences in effect, cognition, and psychomotor (Mazzoli Smith, 2021). 
This contains several meanings that can be described as follows, 1) students who are weak, not smart or slow, must follow the flow of thinking of smart students so that more only nod their head which is done as a sign of agreement rather than opinion; 2) smart students often ignore input from weak, not smart or slow students because of their slow thinking skills; 3) not all students are happy or accept wholeheartedly being taught or given instructions by their peers (the general attitude of students is nosy, mocking each other, insulting, considering stupid, poor, weak, and slow); 4) many students need peace of mind to work so that when they work together in groups it will be very disturbing their creative thinking; 5) students who are traumatized as a result of inadequate or unpleasant learning experiences from teachers (teachers who are rude, impatient, angry, or punitive) are calmer when working separately without teacher supervision; 6) in a short time, students who are weak or have low academic ability, are not smart or slow, are in a hurry to complete their work so that their learning outcomes are incomplete, unfinished, or wrong (Öhrstedt \& Lindfors, 2018).

The facts above indicate that efforts must be made to accommodate all students, whether students with high, medium, and low academic abilities in learning physical education. This process is expected to be not just an ordinary activity. However, attention to low academic students or those who need help in learning can be given. Previous research has been developed and is now being pursued to provide information on students' learning outcomes in various subjects at the elementary level and at other levels, especially very suitable in developing aspects of students' emotional intelligence and learning outcomes. Therefore, students are treated humanely according to their dignity so that they are free from fear or anxiety and other things that interfere with the psychological condition of students during learning. Previous research found that emotional intelligence can increase students' positive feelings physically in the form of psychological feelings (Siskos et al., 2012). Several other studies have also examined emotional intelligence in improving social skills due to the activities of students who often do brawls at school (Vila et al., 2021). In addition, other findings reveal the relationship between student's emotional intelligence and their parents, whose influence in improving students' academic learning outcomes (Vahedi \& Nikdel, 2011). Although there have been many studies on emotional intelligence, there are no studies that report the effect of emotional intelligence on elementary school students' learning outcomes in physical education learning. In addition, previous studies only examined the effects of emotional intelligence separately. They did not examine the effect on students' learning outcomes in elementary school. It is deemed necessary to examine students' learning outcomes and emotional intelligence by research. Thus, the purpose of this study is to analyze the relationship between emotional intelligence and physical education learning outcomes of students in elementary schools.

\section{METHOD}

This correlational study aims to analyze the relationship of emotional intelligence to students' learning outcomes in elementary schools. Emotional intelligence is a predictor variable, and learning outcomes are criterion variables. The scope of emotional intelligence consists of self-awareness, self-regulation, motivation, empathy, and fostering relationships with others as developed by Goleman in 1998 (Furnham, 2014), as shown in Table 1. The learning outcome referred to in the study is emotional intelligence that has the potential to improve students' learning outcomes in physical education.

This research is conducted at the elementary level education unit in Ambon City by considering the level of school category based on the accreditation rating. The population in this study is the fourth-grade elementary school students in Ambon City. The sample consists of 75 the fourth-grade students from five elementary schools in Ambon City, which Cluster Random Sampling determined. This study is in line with research conducted on the first-grade students in a district in Texas with a sample of 538 people practicing English to encourage students' learning outcomes because it is found that students' reading skills are still meager (Hughes et., 2017). The research instruments applied in data collection are: 1) The instrument of the test questions in the form of pretest and posttest questions to measure cognitive learning outcomes in physical education. Before this question is applied to the actual class, expert validation is carried out by two experts. The one is on elementary school learning from the State University of Malang, while the other is on 
sports learning from the State University of Surabaya. In addition, the instrument has been tested on several elementary school students in Ambon City with validity (0.72) and reliability (0.94). Test questions are developed based on subjects, grade levels, themes, and sub-themes currently being taught, and 2) Emotional intelligence instruments. The research data are analyzed by linear regression inferential statistics using SPSS 16.00 for Windows software. Before testing the hypothesis, several prerequisite tests according to research interests are carried out first.

Table 1. Emotional Intelligence Questionnaire

\begin{tabular}{|c|c|c|}
\hline Variable & Factors & Indicators \\
\hline \multirow{23}{*}{ Emotional Intelligence } & 1. Recognizing Your Own Emotions & 1.1 Recognize and feeling self-emotions \\
\hline & \multirow{8}{*}{ 2. Managing Emotions } & $\begin{array}{l}\text { 1.2 Understand the causes of feelings } \\
\text { occured }\end{array}$ \\
\hline & & $\begin{array}{l}\text { 1.3 Recognize the influence of feelings } \\
\text { on actions }\end{array}$ \\
\hline & & 2.1 Be tolerant of frustration \\
\hline & & $\begin{array}{l}2.2 \text { Be able to express anger } \\
\text { appropriately }\end{array}$ \\
\hline & & $\begin{array}{l}\text { 2.3 Be able to control aggressive } \\
\text { behavior that can damage self and } \\
\text { others }\end{array}$ \\
\hline & & $\begin{array}{l}\text { 2.4 Have positive feelings about oneself } \\
\text { and the environment }\end{array}$ \\
\hline & & 2.5 Have the ability to cope with stress \\
\hline & & $\begin{array}{l}\text { 2.6 Can reduce feelings of anxiety and } \\
\text { loneliness in association }\end{array}$ \\
\hline & \multirow[t]{3}{*}{ 3. Motivating Yourself } & 3.1 Be able to do self-control \\
\hline & & $\begin{array}{l}\text { 3.2 Be optimistic in dealing with } \\
\text { problems }\end{array}$ \\
\hline & & 3.3 Be able to focus on the given task \\
\hline & \multirow[t]{3}{*}{ 4. Recognizing Other People's Emotions } & $\begin{array}{l}\text { 4.1 Be able to accept other people's } \\
\text { point of view }\end{array}$ \\
\hline & & $\begin{array}{l}\text { 4.2 Have empathy or sensitivity towards } \\
\text { others }\end{array}$ \\
\hline & & 4.3 Be able to listen to others \\
\hline & \multirow[t]{8}{*}{ 5. Building Relationships } & $\begin{array}{l}5.1 \text { Understand the importance of } \\
\text { building relationships with others }\end{array}$ \\
\hline & & $\begin{array}{l}\text { 5.2 Be able to resolve conflicts with } \\
\text { others }\end{array}$ \\
\hline & & $\begin{array}{l}\text { 5.3 Have the ability to communicate } \\
\text { with others }\end{array}$ \\
\hline & & $\begin{array}{l}\text { 5.4 Have a friendly nature or easy to get } \\
\text { along with others }\end{array}$ \\
\hline & & $\begin{array}{l}\text { 5.5 Have concern for the interests of } \\
\text { others }\end{array}$ \\
\hline & & 5.6 Can live in harmony with the group \\
\hline & & 5.7 Be happy to share and cooperate \\
\hline & & 5.8 Be mature and tolerant \\
\hline
\end{tabular}

\section{RESULTS AND DISCUSSION}

In the research results section, the research results related to the results of statistical analysis tests are described. This study aims to examine the relationship between emotional intelligence and cognitive learning outcomes in physical education subjects. The research is conducted by giving full authority to 
physical education teachers to conduct learning to students. The results of the prerequisite test provide information that the data is normally distributed (0.788) and homogeneous is 0.136 .

\section{Data Description}

The results of descriptive data analysis show that the mean of emotional intelligence and learning outcomes are 69.01 and 64.01 respectively. Thus, the score of emotional intelligence is 5 points higher than the score of cognitive learning outcomes. The range of emotional intelligence scores is 49.00-35.83, while the range of cognitive learning outcomes is 35.83-92.83. The description of students' cognitive learning outcomes and emotional intelligence is shown in Table 2 below.

Table 2. Description of Emotional Intelligence Data and Learning Outcomes

\begin{tabular}{cccccc}
\hline Variable & Sample & Minimum Score & Maximum Score & Mean & Std. Deviation \\
\hline $\begin{array}{c}\text { Emotional } \\
\begin{array}{c}\text { Intelligence } \\
\text { Learning outcomes } \\
\text { Cognitive }\end{array}\end{array}$ & 75 & 49.00 & 86.00 & 69.01 & 8.52 \\
\hline
\end{tabular}

\section{Hypothesis Testing}

Based on the results of ANOVA as shown in Table 3, it is known that the significance value of 0.224 is greater than alpha 0.05, it means that there is no relationship between emotional intelligence and students' cognitive learning outcomes in physical education subjects.

Table 3. Summary of ANOVA Correlation between Emotional Intelligence and Learning Outcomes

\begin{tabular}{llrrrrr}
\hline & Model & Sum of Squares & df & Mean Square & F & Sig. \\
\hline \multirow{2}{*}{1} & Regression & 269.775 & 1 & 269.775 & 1.506 & $.224^{\mathrm{a}}$ \\
\cline { 2 - 7 } & Residual & 13080.776 & 73 & 179.189 & & \\
\cline { 2 - 7 } & Total & 13350.551 & 74 & & & \\
\hline
\end{tabular}

a. Dependent Variable: Cognitive Learning Outcomes

b. Predictors: (Constant), Emotional Intelligence

The amount of the contribution of emotional intelligence to learning outcomes is shown in Table 4.

Table 4. Summary of Linear Regression between Emotional Intelligence and Learning Outcomes

\begin{tabular}{lrccc}
\hline & & & Model Summary & \\
\hline Model & $\mathbf{R}$ & R Square & Adjusted R Square & Std. Error of the Estimate \\
\hline 1 & $.142^{\mathrm{a}}$ & .020 & .007 & 13.38614 \\
\hline
\end{tabular}

a. Predictors: (Constant), KecEmo

The R-value of the correlation between emotional intelligence and cognitive learning outcomes is 0.142 , and the $\mathrm{R}^{2}$ value is 0.020 or $2 \%$. Thus, emotional intelligence contributes $2 \%$ to students' learning outcomes, and other factors contribute as much as $98 \%$.

From Table 5, the regression equation resulting from the relationship between emotional intelligence and learning outcomes can be determined. The value of $\mathrm{a}=48,543$ and $\mathrm{b}=0.224$, so the regression equation $\mathrm{Y}=$ $48,543+0.224 \mathrm{X}$.

Table 5. Regression Coefficient Value between Emotional Intelligence and Learning Outcomes

\begin{tabular}{|c|c|c|c|c|c|c|}
\hline \multicolumn{7}{|c|}{ Coefficients $^{a}$} \\
\hline & \multirow{2}{*}{ Model } & \multicolumn{2}{|c|}{ Unstandardized Coefficients } & Standardized Coefficients & \multirow{2}{*}{$\mathrm{t}$} & \multirow{2}{*}{ Sig. } \\
\hline & & B & Std. Error & Beta & & \\
\hline \multirow[t]{2}{*}{1} & (Constant) & 48.543 & 12.700 & & 3.822 & .000 \\
\hline & Kec.Emo & .224 & .183 & .142 & 1.227 & .224 \\
\hline
\end{tabular}

a. Dependent Variable: HB 
The study results prove that there is no linear correlation between emotional intelligence and students' learning outcomes. This means that the emotional intelligence of students does not determine students' learning outcomes. Based on the results of this study, it is found that the relationship between emotional intelligence and learning outcomes in students, especially elementary school students in physical education subjects, is an anomaly.

The emotional intelligence of students, especially elementary school students who are at the stage of concrete operational development, needs the help of others. The environment inside and outside the home, including the school environment, dramatically affects students' emotional intelligence. Sumarno (2015) states that children need the help of others in their development period, especially emotional development. As chronological age and psychological maturity develop the child's level of dependence on others decreases (Chopik et al., 2018). Elementary school students are highly dependent on parents and teachers when they are in the school environment (Wanders et al., 2020). The students may develop themselves continuously and can also develop the potential in them. However, there must be something else felt by the children. The nature of humanity encourages children to need the help of others in their emotional development. Parents and teachers are the closest people who can encourage children's emotional development (Xiao et al., 2020).

The relationship between emotional intelligence and learning outcomes ensures that students with good emotional intelligence can obtain good learning outcomes and vice versa (Khan, 2019). In this regard, Petrides et al. (2004) explained that one factor that influences a person's emotional intelligence is personality. Students with good personalities must have good emotional intelligence. On the other hand, students with bad personalities must display poor emotional intelligence (Chen \& Guo, 2020). Bad personality can be seen through the following indicators: lack/no motivation, loss of self-confidence, low self-esteem, loss of self-control, and high anxiety (Crocker \& Park, 2004). If a student shows these characteristics, this shows that his emotional intelligence is low and has a fatal impact on his/her learning outcomes.

The development of the industrial revolution brings various changes in human life. Human emotions, including children, are disturbed by various phenomena around them. Parents' emotions are also disturbed, thinking about the fate of the life that is currently being lived, exacerbated by economic downturn so that anxiety always occurs (Akpan et al., 2020). These emotional problems also shape the child's personality (Somma et al., 2020). One of the most prominent emotional problems is stress (Obeid et al., 2020). During the COVID-19 pandemic, attention to information related to COVID-19 and concerns about health can act as cognitive stressors that trigger negativity, especially in individuals with high neuroticism, namely affective reactivity. Stronger affective reactivity may contribute to increased negative affect and increased affective variability. The relationship between stress and affective reactivity is an objective cause of daily stress that is generally experienced by parents and can be shown to children (Kroencke et al., 2020).

Children's social and learning environment are minimized due to the lack of supporting facilities in the form of internet access to access the latest information. As a result, children's emotional development is limited, and children can only learn from one environment, namely the family environment. These things cause children's emotional intelligence to be less developed. Emotional intelligence plays a role in increasing student achievement (Hogan et al., 2010). In the learning process, emotional intelligence is needed by students to understand the lessons delivered by the teacher because intellectuals alone cannot function properly without emotional appreciation in each lesson (Juravich \& Babiak, 2015). Emotional intelligence determines how well students can use other intelligence, including IQ (Odaci et al., 2017).

The results of previous studies have reported a linear relationship between emotional intelligence and students' learning outcomes through the application of learning models (Kumar et al., 2019). Herpratiwi et al.'s (2018) and Morgan (2019) research found that it can encourage an increase in students' emotional intelligence by applying the learning model. Students are very active and enthusiastic during the learning process. The results of other studies show that athletes who are successful in sports can manage emotional intelligence well (Gribble et al., 2018). Similarly, good emotional intelligence students will increase academic achievement in physical education learning (Richards et al., 2019). Learning outcomes are indicators that make students able to control their emotions and respect each friend's opinion when in the 
learning process. This relevance is in line with Leasa and Corebima's (2017) research, reporting the contribution of emotional intelligence to student learning outcomes by $4.8 \%$. The results of studies on athletic learning in high school students in the USA show that if someone is intelligent, cooperative, and has a proliferative emotional state, it creates a more effective learning process, and students are more professional (Lee et al., 2020). The model or strategy in learning is indirectly able to grow students' emotional intelligence which in the end also affects students' physical and cognitive dimensions (Peachey et al., 2017).

Based on the description of the study, it is found that there is no correlation between emotional intelligence and elementary school students' learning outcomes in physical education subjects. This is caused by various factors, including, 1) the implementation of online learning is less than optimal because it is not supported by adequate facilities and learning participation by all students, reduced or limited interaction between students and the learning environment, 2) the economic burden that causes emotional problems on parents that impacts children's emotions, 3) the pattern of children's character formation during the pandemic which is more of the responsibility of the parents. Other factors are also related to economic factors, where parents are busy looking for efforts to fulfill family food needs. As a result, parents' attention to their children's emotions gets less attention.

\section{CONCLUSION}

The results of the research and discussion conclude that the ANOVA correlation between emotional intelligence and physical education learning outcomes shows a significance value of 0.224 , which is greater than alpha 0.05. It implies no correlation between emotional intelligence and students' cognitive learning outcomes in physical education subjects. Some factors contribute to the absence of a relationship between emotional intelligence and learning outcomes; the implementation of learning that is less than optimal because it is not supported by adequate facilities and learning participation by all students, reduced or limited interaction between students and the learning environment, and economic burden that causes emotional problems on parents and impact children's emotions. The contribution of emotional intelligence to the achievement of learning outcomes, especially in physical education subjects, is as much as $2 \%$ and other factors contribute as much as $98 \%$. Based on these conclusions, suggestions that can be given include, 1) Extra teacher assistance is for students so that it can help students' emotional formation, 2) It is necessary to provide adequate learning facilities such as supporting tools for learning physical education, so that theory and practice can take place smoothly so as to encourage learning outcomes to the expected goals, 3) Further research is needed that examines the effectiveness of online learning on the emotional intelligence of elementary school students. The research is only limited to elementary school students and it is hoped that further research can measure students' emotional intelligence at other levels, for example, in secondary, higher, and even non-formal education.

\section{ACKNOWLEDGEMENT}

This research is a part of the Research Grant of Faculty of Teacher Training and Education, Universitas Pattimura, Indonesia. Decree No. 422/UN13.1.3/SK/2020, led by Albertus Fenanlampir.

\section{CONFLICT OF INTEREST}

The authors declare no conflict of interest.

\section{REFERENCES}

Akpan, I. J., Soopramanien, D., \& Kwak, D. H. (2020). Cutting-edge technologies for small business and innovation in the era of COVID-19 global health pandemic. Journal of Small Business and Entrepreneurship, O(0), 1-11. https://doi.org/10.1080/08276331.2020.1799294 
Ang, S. C., \& Penney, D. (2013). Promoting social and emotional learning outcomes in physical education: Insights from a school-based research project in Singapore. Asia-Pacific Journal of Health, Sport and Physical Education, 4(3), 267-286. https://doi.org/10.1080/18377122.2013.836768

Arikan, N. (2020). Effect of sport education model-based social-emotional learning program on emotional intelligence. International Education Studies, 13(4), 41. https://doi.org/10.5539/ies.v13n4p41

Arribas-Galarraga, S., Luis-De-Cos, I., Cecchini, J. A., Saies, E., \& Cos, G. L. De. (2020). Influence of emotional intelligence on sport performance in elite canoeist. Journal of Human Sport and Exercise, 15(4), 772-782. https://doi.org/10.14198/jhse.2020.154.05

Batlolona, J. R., Diantoro, M., Wartono, \& Leasa, M. (2020). Students' mental models of solid elasticity: Mixed method study. Journal of Turkish Science Education, 17(2), 200-210. https://doi.org/10.36681/tused.2020.21

Batlolona, J. R., \& Souisa, H. F. (2020). Problem based learning: Students' mental models on water conductivity concept. International Journal of Evaluation and Research in Education, 9(2), 269-277. https://doi.org/10.11591/ijere.v9i2.20468

Berkovits, D. M. (2014). A study of motivational influences on academic achievement. Social Psychology of Education, 17(2), 327-342. https://doi.org/10.1007/s11218-014-9257-7

Chan, J., \& Mallett, C. (2011). The value of emotional intelligence for high performance coaching. International Journal of Sports Science and Coaching, 6(3), 315-328. https://doi.org/10.1260/17479541.6.3.315

Chen, J., \& Guo, W. (2020). Emotional intelligence can make a difference: The impact of principals' emotional intelligence on teaching strategy mediated by instructional leadership. Educational $\begin{array}{llll}\text { Management Administration } & \text { and }\end{array}$ https://doi.org/10.1177/1741143218781066

Chopik, W. J., Bremner, R. H., Johnson, D. J., \& Giasson, H. L. (2018). Age differences in age perceptions and developmental transitions. Frontiers in Psychology, 9(67), 1-10. https://doi.org/10.3389/fpsyg.2018.00067

Crocker, J., \& Park, L. E. (2004). The costly pursuit of self-esteem. Psychological Bulletin, 130(3), 392414. https://doi.org/10.1037/0033-2909.130.3.392

Darling-hammond, L., Flook, L., Cook-harvey, C., Barron, B., Flook, L., Cook-harvey, C., Barron, B., Darling-hammond, L., Flook, L., Cook-harvey, C., \& Barron, B. (2019). Implications for educational practice of the science of learning and development. Applied Developmental Science, 24(2), 1-44. https://doi.org/10.1080/10888691.2018.1537791

de Souza, L. N., Kowaltowski, D. C. C. K., Woolner, P., \& Moreira, D. de C. (2020). School design patterns supporting learning through play. International Journal of Play, 9(2), 202-229. https://doi.org/10.1080/21594937.2020.1757204

Dishon-Berkovits, M. (2014). A study of motivational influences on academic achievement. Social Psychology of Education, 17(2), 327-342. https://doi.org/10.1007/s11218-014-9257-7

Furnham, A. (2014). Emotional Intelligence - New Perspectives and Applications. University of Florence. https://doi.org/10.5772/31079

Galarraga, A. S., Luis, D. C. I., Cecchini, J. A., Saies, E., \& Cos, G. L. D. (2020). Influence of emotional intelligence on sport performance in elite canoeist. Journal of Human Sport and Exercise, 15(4), 772782. https://doi.org/10.14198/jhse.2020.154.05 
Goodyear, V., \& Dudley, D. (2015). "I'm a facilitator of learning!" understanding what teachers and students do within student-centered physical education models. Quest, 67(3), 274-289. https://doi.org/10.1080/00336297.2015.1051236

Gribble, N., Ladyshewsky, R. K., \& Parsons, R. (2018). Changes in the emotional intelligence of occupational therapy students during practice education: A longitudinal study. British Journal of Occupational Therapy, 81(7), 413-422. https://doi.org/10.1177/0308022618763501

Herpratiwi, Darsono, Sasmiati, \& Pujiyatli. (2018). Cooperative learning and learning achievement in social science subjects for sociable students. Egitim Arastirmalari - Eurasian Journal of Educational Research, 2018(75), 81-98. https://doi.org/10.14689/ejer.2018.75.5

Hogan, M. J., Parker, J. D. A., Wiener, J., Watters, C., Wood, L. M., \& Oke, A. (2010). Academic success in adolescence: Relationships among verbal IQ, social support and emotional intelligence. Australian Journal of Psychology, 62(1), 30-41. https://doi.org/10.1080/00049530903312881

Hughes, J. N., Cao, Q., West, S. G., Allee Smith, P., \& Cerda, C. (2017). Effect of retention in elementary grades on dropping out of school early. Journal of School Psychology, 65, 11-27. https://doi.org/10.1016/j.jsp.2017.06.003

Ingram, A., Peake, W. O., Stewart, W., \& Watson, W. (2019). Emotional intelligence and venture performance. Journal of Small Business Management, 57(3), 780-800. https://doi.org/10.1111/jsbm.12333

Jan, S. U., \& Anwar, M. A. (2019). Emotional intelligence, library use and academic achievement of university students. Journal of the Australian Library and Information Association, 68(1), 38-55. https://doi.org/10.1080/24750158.2019.1572482

Janssen, I., \& Leblanc, A. G. (2015). Systematic review of the health benefi ts of physical activity and fitness in school-aged children and youth. School Nutrition and Activity, 209-246. https://doi.org/10.1201/b18227-18

Juravich, M., \& Babiak, K. (2015). Examining positive affect and job performance in sport organizations: a conceptual model using an emotional intelligence lens. Journal of Applied Sport Psychology, 27(4), 477-491. https://doi.org/10.1080/10413200.2015.1048382

Khan, S. (2019). A comparative analysis of emotional intelligence and intelligence quotient among Saudi business students' toward academic performance. International Journal of Engineering Business Management, 11, 1-10. https://doi.org/10.1177/1847979019880665

Koh, S., Napa Scollon, C., \& Wirtz, D. (2014). The role of social relationships and culture in the cognitive representation of emotions. Cognition and Emotion, 28(3), 507-519. https://doi.org/10.1080/02699931.2013.839440

Kroencke, L., Geukes, K., Utesch, T., Kuper, N., \& Back, M. D. (2020). Neuroticism and emotional risk during the Covid-19 pandemic. Journal of Research in Personality, 89, 104038. https://doi.org/10.1016/j.jrp.2020.104038

Kumar, J. A., Muniandy, B., \& Wan Yahaya, W. A. J. (2019). Exploring the effects of emotional design and emotional intelligence in multimedia-based learning: an engineering educational perspective. New Review of Hypermedia and Multimedia, 25(1-2), 57-86. https://doi.org/10.1080/13614568.2019.1596169

Leasa, M., Batlolona, J. R., \& Talakua, M. (2021). elementary students' creative thinking skills in science in the maluku islands, Indonesia. Creativity Studies, 14(1), 74-89 
Leasa, M., Corebima, A. D., Ibrohim, \& Suwono, H. (2017). Emotional intelligence among auditory, reading, and kinesthetic learning styles of elementary school students in Ambon-Indonesia. International Electronic Journal of Elementary Education, 10(1), 83-91. https://doi.org/10.26822/iejee.2017131889

Leasa, M., Talakua, M., \& Batlolona, J. R. (2016). The development of a thematic module based on Numbered Heads Together (NHT) cooperative learning model for elementary students in Ambon, Moluccas-Indonesia. New Educational Review, 46(4), 174-185. https://doi.org/10.15804/tner.2016.46.4.15

Lee, Y. H., R. Richards, K. A., \& Washhburn, N. S. (2020). Emotional intelligence, job satisfaction, emotional exhaustion, and subjective well-being in high school athletic directors. Psychological Reports, 123(6), 2418-2440. https://doi.org/10.1177/0033294119860254

Liu, L. W., Huang, R. R., Chang, C. M., \& Liu, C. Y. (2017). The design consideration of outdoor playground: From elementary school student's perceived attraction and satisfaction. Studies on EthnoMedicine, 11(1), 35-44. https://doi.org/10.1080/09735070.2017.1311706

Longobardi, C., Badenes-Ribera, L., \& Fabris, M. A. (2020). Emotional intelligence in child molesters. Journal of Forensic Psychology Research and Practice, 20(4), 377-394. https://doi.org/10.1080/24732850.2020.1742016

Mazzoli, S. L. (2021). The ability trap: reductionist theorising about academic ability and the ramifications for education policy and school-based practice. Cambridge Journal of Education, 51(1), 85-103. https://doi.org/10.1080/0305764X.2020.1782351

Morgan, K. (2019). Applying mastery target structures to cooperative learning in physical education. Journal of Physical Education, Recreation and Dance, 90(3), 27-32. https://doi.org/10.1080/07303084.2019.1559677

Obeid, S., Lahoud, N., Haddad, C., Sacre, H., Fares, K., Akel, M., Salameh, P., \& Hallit, S. (2020). Factors associated with anxiety among the Lebanese population: the role of alexithymia, self-esteem, alcohol use disorders, emotional intelligence and stress and burnout. International Journal of Psychiatry in Clinical Practice, 24(2), 151-162. https://doi.org/10.1080/13651501.2020.1723641

Odaci, H., Değerli, F. I., \& Bolat, N. (2017). Emotional intelligence levels and counselling skills of prospective psychological counsellors. British Journal of Guidance and Counselling, 45(5), 622-631. https://doi.org/10.1080/03069885.2017.1379596

Öhrstedt, M., \& Lindfors, P. (2018). Linkages between approaches to learning, perceived stress and expected and actual academic outcomes among first-semester psychology students. Journal of Further and Higher Education, 42(1), 116-129. https://doi.org/10.1080/0309877X.2016.1206856

Omer, I. (2018). Effect of city form and sociospatial divisions on cognitive representation of an urban $\begin{array}{llll}\text { environment. Journal } & \text { Affairs, } & \text { 40(4), } & \text { 560-575. }\end{array}$ https://doi.org/10.1080/07352166.2017.1360738

Peachey, A. A., Wenos, J., \& Baller, S. (2017). Trait emotional intelligence related to bullying in elementary school children and to victimization in boys. OTJR Occupation, Participation and Health, 37(4), 178187. https://doi.org/10.1177/1539449217715859

Petrides, K. V., Frederickson, N., \& Furnham, A. (2004). The role of trait emotional intelligence in academic performance and deviant behavior at school. Personality and Individual Differences, 36(2), 277-293. https://doi.org/10.1016/S0191-8869(03)00084-9 
Richards, K. A., Washburn, N. S., \& Hemphill, M. A. (2019). Exploring the influence of perceived mattering, role stress, and emotional exhaustion on physical education teacher/coach job satisfaction. European Physical Education Review, 25(2), 389-408. https://doi.org/10.1177/1356336X17741402

Siskos, B., Proios, M., \& Lykesas, G. (2012). Relationships between emotional intelligence and psychological factors in physical education. Studies in Physical Culture and Tourism, 19(3), 154-159.

Somma, A., Gialdi, G., Krueger, R. F., Markon, K. E., Frau, C., Lovallo, S., \& Fossati, A. (2020). Dysfunctional personality features, non-scientifically supported causal beliefs, and emotional problems during the first month of the COVID-19 pandemic in Italy. Personality and Individual Differences, 165, 110139. https://doi.org/10.1016/j.paid.2020.110139

Sukys, S., Tilindienè, I., Cesnaitiene, V. J., \& Kreivyte, R. (2019). Does Emotional Intelligence Predict Athletes' Motivation to Participate in Sports? Perceptual and Motor Skills, 126(2), 305-322. https://doi.org/10.1177/0031512518825201

Sumarno. (2015). Model konstruk kecerdasan emosional siswa SD. Sekolah Dasar: Kajian Teori dan Praktik Pendidikan, 24(1), 26-33.

Tomporowski, P. D., Davis, C. L., Miller, P. H., \& Naglieri, J. A. (2008). Exercise and children's intelligence, cognition, and academic achievement. Educational Psychology Review, 20(2), 111-131. https://doi.org/10.1007/s10648-007-9057-0

Vahedi, M., \& Nikdel, H. (2011). Emotional intelligence, parental involvement and academic achievement. Procedia - Social and Behavioral Sciences, 30, 331-335. https://doi.org/10.1016/j.sbspro.2011.10.065

Vaughan, R., Laborde, S., \& McConville, C. (2019). The effect of athletic expertise and trait emotional intelligence on decision-making. European Journal of Sport Science, 19(2), 225-233. https://doi.org/10.1080/17461391.2018.1510037

Vila, S., Gilar-Corbí, R., \& Pozo-Rico, T. (2021). Effects of student training in social skills and emotional intelligence on the behaviour and coexistence of adolescents in the 21st century. International Journal of Environmental Research and Public Health, 18(10). https://doi.org/10.3390/ijerph18105498

Wanders, F. H. K., Dijkstra, A. B., Maslowski, R., \& van der Veen, I. (2020). The effect of teacher-student and student-student relationships on the societal involvement of students. Research Papers in Education, 35(3), 266-286. https://doi.org/10.1080/02671522.2019.1568529

Xiao, E., Shen, J., \& Harris, P. (2020). Children with siblings differ from only children in their sharing behaviour. Early Child Development and Care, O(0), 1-13. https://doi.org/10.1080/03004430.2020.1829610

Yan, E. M., Evans, I. M., \& Harvey, S. T. (2011). Observing emotional interactions between teachers and students in elementary school classrooms. Journal of Research in Childhood Education, 25(1), 82-97. https://doi.org/10.1080/02568543.2011.533115

Zeng, N., Ayyub, M., Sun, H., Wen, X., Xiang, P., \& Gao, Z. (2017). Effects of physical activity on motor skills and cognitive development in early childhood: a systematic review. BioMed Research International, 1-13. https://doi.org/10.1080/08276331.2020.1790167 